\title{
複雑な環境下における指示物体の把持*
}

\author{
永田 和之*1, 宮坂 崇*2, 金宮 好和 ${ }^{* 3}$, 山野辺 夏樹 ${ }^{* 1}$ \\ 丸山 健一 ${ }^{* 4}$, 川端 聡*5, 河井 良浩 ${ }^{* 5}$
}

\section{Grasping an Indicated Object in a Complex Environment}

\section{Kazuyuki NAGATA*1 , Takashi MIYASAKA, Yoshikazu KANAMIYA, Natsuki YAMANOBE, Kenichi MARUYAMA, Satoshi KAWABATA and Yoshihiro KAWAI}

\author{
${ }^{* 1}$ Intelligent Systems Research Institute, National Institute of Advanced Industrial Science and Technology (AIST), \\ Central 2, 1-1-1 Umezono, Tsukuba, Ibaraki, 305-8568, Japan
}

This paper presents a task instruction system for picking up an indicated object in a complex environment. The basic setup of the system consists of a manipulator, a stereo camera, and a monitor. The task instruction scheme comprises the following four main steps: 1) The user indicates the target object on the camera image by a mouse click, and selects the object category and grasping form from a pop-up list. In this way, the system obtains information about the 3D position coordinates of the clicked point on the target object, the primitive shape of the object, and the task model for object picking with the selected grasping form. 2) The system acquires the information about the target object and constructs an environment model around the target by stereo vision using the information obtained from the task instruction. 3) The system finds a grasp point based on a grasp evaluation using the acquired information. 4) The robot performs picking up the indicated object. The features of the scheme are that the user can easily instruct the robot how to perform the object picking task by simple clicking operation, and the robot can pick up the indicated object placed in a complex environment without any previous knowledge of the target object.

Key Words : Grasp Planning, Task Instruction, Object Picking, Daily Life Environment

\section{1. は じ め に}

少子高齢化社会を背景に，高齢者や身体に障害がある人の生活をサポートする生活支援ロボットの研究開発が 盛んに行われている．生活支援ロボットに期待される作業には，日常のあらゆる作業が含まれるが，この中でも人 が指示した物を取ってくる作業はニーズが高く重要である。ロボットで人が指示した物を取るためには，複数の 物体の中から対象物を指定する作業指示と, 複雑な環境下での物体把持が重要課題となる. 物体把持の観点から 日常生活環境を眺めると，1) ロボットが扱う対象物は我々の身の回りにあるあらゆるもので，同じ種類の物体で も様々な意匠・大きさの物が存在する，2) 対象物が単体で環境に置かれていることは少なく，他の物体に取り囲 まれている，3) ロボットばかりでなく人も物を移動するので，対象物の置かれている状態が予め分からない，と いった特徵がある。この様な複雑な環境下では，作業に必要な情報を全てロボットが自律的に取得して作業を行 うことは難しい. 一方, 全ての作業をユーザが遠隔操作で行うことは，ユーザに大きな負担をかける。この場合， ロボットが自律的に行える部分についてはロボットが実行し, ロボットが自律的に取得することが困難な情報を ユーザがロボットに教示する Shared Autonomy ${ }^{(1)}$ が有効である.

\footnotetext{
* 原稿受付 2012 年 8 月 13 日

$*_{1}$ 正員, (独) 産業技術総合研究所知能システム研究部門

( (305-8568 茨城県つくば市梅園 1-1-1 中央第二)

*2 三菱電機 (株)

*3 正員, 東京都市大学工学部機械システム工学科（テ158-8557 東京都世田谷区玉堤 1-28-1）

$*_{4}^{*}$ セイコーエプソン (株)

*5 (独) 産業技術総合研究所知能システム研究部門 （テ305-8568 茨城県つくば市梅園 1-1-1 中央第二）
} E-mail: k-nagata@aist.go.jp 
これまで, 日常生活環境における物体把持の関連研究として, 多様な物体を単純な形状のプリミティブの組合せ でモデル化し，把持計画を行う研究が行われている ${ }^{(2) ~(5)}$. Ekvall らは, 対象物のプリミティブモデルと, 人によ るデモンストレーションデータを用いて, 物体把持のためのアプローチ動作を計画した ${ }^{(3)}$. Berenson らは, アー ムのキネマティクス, Force Closure, 障害物とのクリアランスを評価指標に, 複雑な環境下に置かれた物体の把持 計画を行った ${ }^{(4)}$. これらの研究は, 予め対象物の形状や配置に関する情報を必要とした. 一方, 個々の対象物に関 する事前情報を用いることなく，視覚により物体情報を獲得して把持計画を行う研究が行われている ${ }^{(5)(6)}$. しか し, これらの研究は, 対象物が単品で環境に置かれている場合を扱っており, 周りに他の物体が存在する場合につ いては扱っていない.

また，マーク ${ }^{(7)}$ PFID ${ }^{(8)}$ に予め物体情報を記述しておき，これらの情報を利用してロボットで物体をハンドリ ングする研究が行われている. マークやRFID を用いることで, 複雑な環境下での物体認識の問題を緩和すること ができる.しかし，日常生活環境には膨大な数と種類の物があり，これら一つひとつについてマークやRFIDを添 付し，物体情報を記述しておくことは現実的ではない.

人の指示に基づく物体把持の研究として，人とロボットとが音声により対話を行いながら，人が指示した物を 視覚により認識して取り上げる研究がある ${ }^{(9)}$.この研究では，物体認識のために個々の対象物に関する事前情報が 必要となる。その他に, 作図によりカメラ画像上にプリミティブ図形を重ね合わせ, プリミティブ図形の辺や面 を指定することで把持点を教示する研究 ${ }^{(10)(11)}$, 環境や人・物を仮想的なボタンと見なし，レーザポインタで仮想 ボタンをポインティングすることでロボットに作業指示を行う研究 ${ }^{(12)}$ が行われている.

これまで我々は，日常環境のような複雑な環境下で，人が指定した物を取って来るロボットの実現を目指して， 人が指示した物を取り上げる作業指示システムの研究を実施してきた ${ }^{(13)}$. 本作業指示システムは Shared Autonomy の考えを取り入れ，ロボットが自律的に取得できる情報はロボットが取得し，ユーザの意図や意思に委ねられる情 報や，ロボットが自律的に取得することが困難な情報を，ユーザが作業指示によりロボットに教示した．我々は， ロボットへの作業指示は, ユーザに高度な知識や複雑な操作を要求するのではなく, 直感的で簡単に行えなければ ならないと考えている。また，日常生活環境にある多種多様な物体をハンドリングするためには，個々の対象物 に関する事前情報を用いない手法が有効であると考えている，そこで我々は，個々の対象物に関する事前情報を 用いることなく, 数回のクリック操作とメニュー選択という簡単な操作により作業指示が行えるシステムを提案 してきた．この作業指示システムでは，物体のカテゴリ毎に定義された物体モデルのライブラリが用意されてお り, 各物体モデルには, 物体が置かれた状態や使用目的に応じた様々な物体の取り方の作業モデルが記述されてい る. ユーザはディスプレイに表示されたカメラ画像上で, 対象物をマウスクリックすることで対象物を直接指定 し, 対象物が属する物体カテゴリとその取り方を, システムがリストアップしたリストの中から選択することで ロボットに作業指示を行った，ところで以前のシステムでは，ハンドリングに必要な把持点の位置を，ユーザが カメラ画像上でクリックすることで直接指定していた. しかし，ステレオカメラの対応点問題により把持点の位 置が得られなかったり，クリック点の誤差のために適切な把持点を指定できないことがあった.

本論文は，これらの問題を解決するために，作業指示で得られた情報を用いて，ステレオビジョンにより対象物 情報の獲得と対象物周辺の環境モデルの構築を行い，これらの情報を用いた把持計画により把持点を自律的に取 得する手法を提案する. 本手法による指示物体の把持は, 図 1 に示すように 1) ユーザによる作業指示，2)物体情 報獲得と環境モデル構築，3）把持計画，4）ロボットによる把持動作実行の四つのステップにより実行される. 本 論文では，まず 2 章において作業指示について述べる. 次に 3 章で対象物情報の獲得と環境モデル獲得について 述べ，4 章で把持計画について述べる. 最後に 5 章で, 本手法を検証するために行った実験結果について述べる. 尚，本研究では，指の開閉のみで把持が完了する把持作業を対象とし，マニピュレーションを伴うような複雑な 把持 ${ }^{(14)}$ は対象としない. また，把持作業の内容は，対象物にアプローチして物体を把持し，持ち上げるところま でとし，ロボットハンドは，一般的な平行二指ハンドを仮定する。

\section{2. ユーザによる作業指示}

人が指定した物をロボットで取り上げるためには，まず，ロボットに取って欲しい物を伝える必要がある。ま た, 日用品は使用目的や用途に応じてその扱い方が異なるため, ロボットは使用目的や用途に応じた把持形態で 
(1)

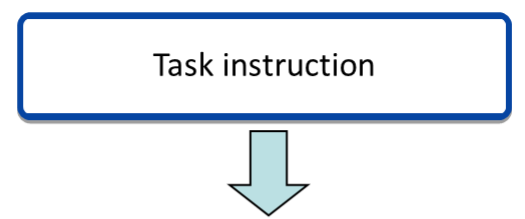

(2)

Object information acquisition

Construction of the 3D

environment model

(3)

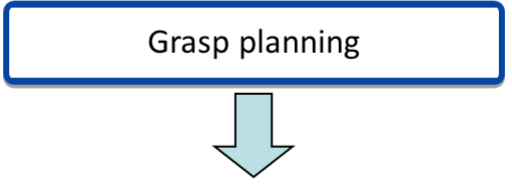

(4)

Task execution

Fig. 1 Object fetching scheme

物を把持する必要がある。このようなユーザの意図や意思に委㸚られる情報は，ユニーザがシステムに直接教示す る必用がある．また，日常生活環境の様に複雑な環境下では，個々の物体に関する事前情報を用いずに，ロボッ トが自律的に物体を識別することは難しい，そこで本作業指示システムでは，Shared Autonomy ${ }^{(1)}$ の考えを取り入 れ，ユーザの意図や意思に委衫られる対象物の指定やその取り方の指定と，ロボットが自律的に取得することが 困難な対象物の種類に関寸る情報を，ユーザによる作業指示によりシステムに与える．本システムでは，ユーザ が直観的にロボットに作業指示が行えるよう, 簡単なクリック操作とメニュー選択によりシステムに作業情報を与 える. 本章では, まず, 数回のクリック操作とメニュー選択による作業指示を可能にするための作業モデル, 物体 モデル，空間モデルについて述べる．次にシステム構成とユーザによる作業指示手順について述べる.

\section{$2 \cdot 1$ 作業モデル}

作業モデルとは，作業に関する知識のことで，作業に必要なパラメータや作業手順のテンプレート，作業条件が 記述されている ${ }^{(15)(16)}$. 作業の実装は, 作業モデルの内容に基づき, ロボットのハードウェアやシステム構成に応 じて行われる. 本作業指示の作業モデルには，指定した把持形態で物体を取り上げるのに必要な作業パラメータ， 作業手順，作業条件が記述されている.

\section{$2 \cdot 2$ 物体モデル}

日常生活環境には多種多様な物体が存在し，あらゆる物が把持対象となる。これらの物体の一つひとつについ て物体モデルを持つことは現実的ではない，ところで，物体が属するカテゴリが共通ならば，物体の形状は類似 しており，扱い方も共通となることが多い，そこで，形状の特徵や扱い方の観点から物体をいくつかのカテゴリ に分け，カテゴリごとに物体モデルを定義する．以前のシステムでは，物体モデルは物体カテゴリに適用できる 物体の取り方（作業モデル）のみを記述していた ${ }^{(13)}$. 本システムの物体モデルは，ステレオビジョンによる対象 物情報の獲得を行うため, 形状に関する情報を含める. 物体モデルでは, 物体カテゴリを代表する形状を, 単純 な形状の物体プリミティブの組合せで記述する．物体プリミティブには，形状を記述するパラメータと，物体プ リミティブの配置を定める座標系が定義されている．形状パラメータには，物体カテゴリが取りうる值の範囲と 代表值を記述しておくことができる．また，各物体プリミティブには，その物体プリミティブに適用可能な代表 


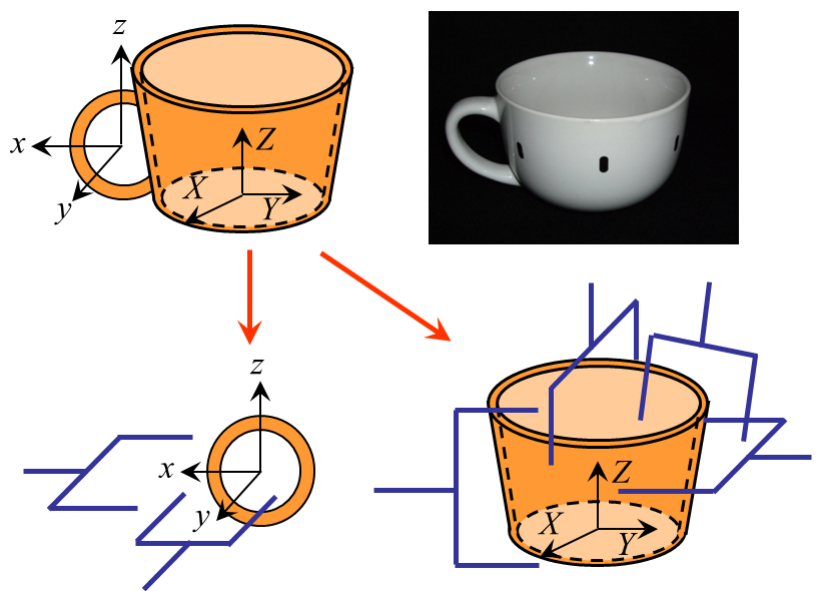

Fig. 2 Object model of a cup

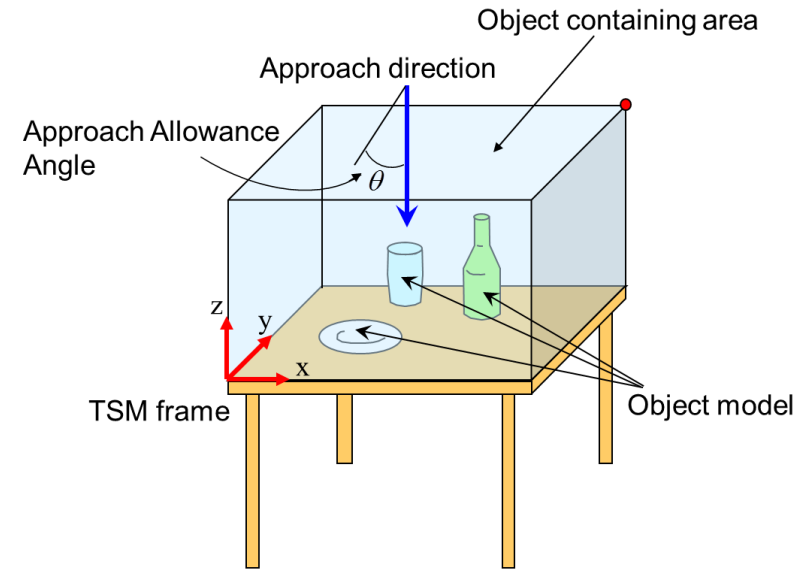

Fig. 3 Task space model of a table

的な把持形態で物体を取り上げるための作業モデルが記述されている. 物体プリミティブとして，テーパー付き 円柱（充填, 中空・底有り, 中空・底無し), テーパー付き四角柱（充填, 中空・底有り, 中空・底無し）, 球の 7 種類を定義した ${ }^{(17)}$. 図 2 はカップの物体モデルの例である.

\section{$2 \cdot 3$ タスク空間モデル (TSM)}

ロボットが作業を行う場合，ロボットや対象物を取り囲む作業環境の情報が必要となる．作業環境の情報は，環 境モデルとしてシステムの中に記述される.ところで日常生活環境では，ロボットばかりでなく人も物を移動する ため，対象物周辺にある物を全て環境モデルとして予めシステムに記述しておくことは現実的ではない。しかし， 家具や建具など空間に固定されている物については，その情報を予めシステムに記述しておくことができる．そ こで，家具や建具など普段人が移動させない物の情報のうち，ロボットの作業に関連する情報をタスク空間モデ ル [Task Space Model (TSM)] と定義する ${ }^{(13)}$. タスク空間モデルには，その場所に置かれる物体が占有し得る空間 領域や, 物体への許容アプローチ方向・許容離脱方向, 扉や引き出しを開閉するための作業モデルなどが記述さ れる。また，タスク空間モデルには，その場所に存在する可能性の高い物体カテゴリの物体モデルを登録したり， 逆に特定の種類の物をその場所に置かなくなった場合には，物体モデルを抹消したりすることができる．例えば， 食器棚には食器の物体モデルが，本棚には本の物体モデルが登録される．このように，タスク空間モデルに物体モ デルを登録したり抹消することで，ユーザの生活空間に合わせて，環境モデルをカスタマイズすることができる.

図 3 は，テーブルのタスク空間モデルの例である.テーブルのタスク空間モデルには，テーブルの配置を記述す るための座標系，テーブル上の物体が占有し得る空間領域 (Object containing area), 対象物への許容アプローチ方 向が記述されており，ユーザがテーブルの上に普段置いている物体カテゴリの物体モデルが登録されている. 対 象物への許容アプローチ方向は, 図 3 の Approach diretion と Approach allowance angle により定義される. 対象物 へのアプローチ方向が以下の条件を満たさない場合，ロボットはテーブル上の物体にアクセスできない.

$$
\frac{\boldsymbol{v} \cdot \boldsymbol{r}}{\|\boldsymbol{v}\|\|\boldsymbol{r}\|} \geq \cos \theta
$$

ここで, $\boldsymbol{r}$ はロボットの対象物へのアプローチ方向, $\boldsymbol{v}$ は Approach direction, $\theta$ は Approach allowance angle である.

タスク空間モデルは，実際の家具や建具の配置に合わせて，部屋の環境モデルに記述される.

\section{4 システム構成}

システムは，ステレオカメラ，マニピュレータ，ディスプレイで構成される，ステレオカメラは，マニピュレー タの手首に取り付けられており, マニピュレータとカメラの位置関係はキャリブレーションにより求められてい 


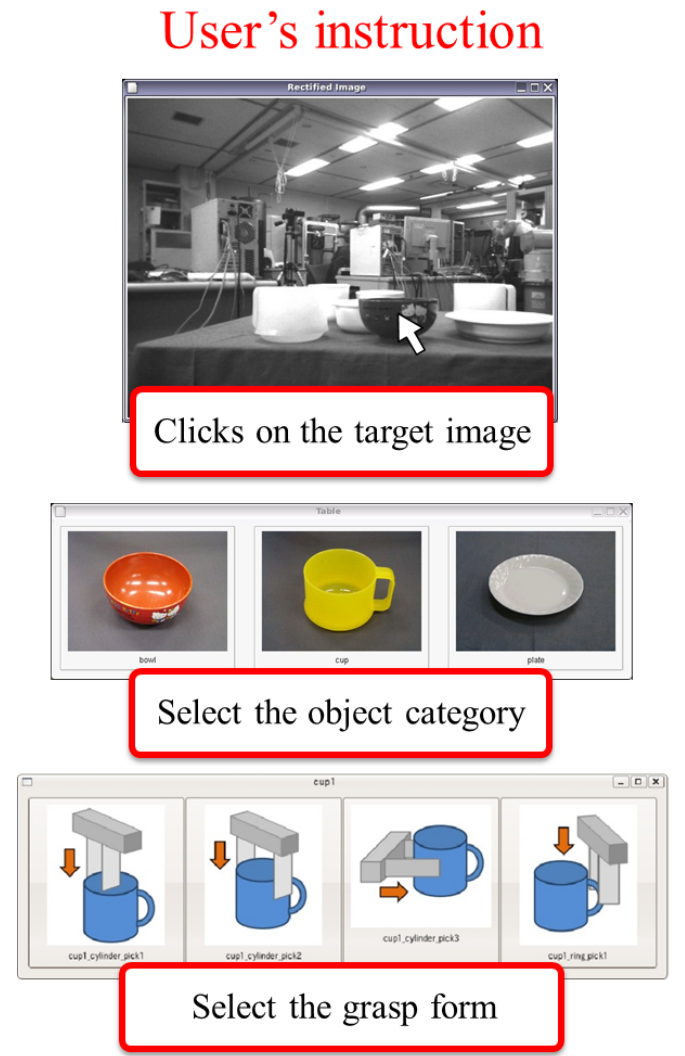

\section{Acquired information}

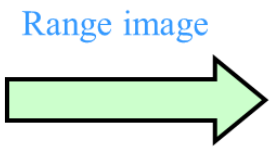

Displays the popup list of the object models

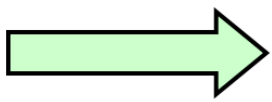

Displays the popup list of the task models
3D position of the clicked point

Task Space model
Object model

(Primitive shape)

Fig. 4 Procedure of the task instruction

る(18). ディスプレイには，手首に取り付けられたカメラから得られる画像が表示されており，ステレオビジョン により距離画像を得ることができる。また，部屋の環境モデルには，家具や建具のタスク空間モデルが実際の配 置に合わせて記述されており, タスク空間モデルには，ユーザが普段置いている物体カテゴリの物体モデルが登 録されている.

\section{5 作業指示手順}

図 4 に作業指示の流れとシステムが獲得する情報について示す．作業指示の手順は以下の通りである.

1) ユーザは，ディスプレイに表示されたカメラ画像上で，対象物をクリックする (図 4 左上). これによりシス テムは，距離画像からクリック点に対応した対象物上の一点の三次元座標を得る.この点の情報から，シス テムは対象物が含まれるタスク空間モデルを選定する。この様に，ユーザが直接対象物を指定するので，ロ ボットは対象物を探索する必要がない。システムは，選定されたタスク空間モデルに登録されている物体モ デルのリストを表示する (図 4 左中).

2) ユーザは，リストアップされた物体モデルの中から，対象物が属する物体カテゴリを選択する。尚，リスト アップされた物体モデルの中に適当な物体モデルがない場合には，物体モデルのライブラリにアクセスして 適当な物体モデルを選択する．物体モデルのライブラリにも適当な物体モデルがない場合には，以降の過程 を全てスキップし，遠隔操作により手動で対象物を把持する. 対象物の物体モデルが選択されると，システ ムは，その物体モデルに記述されている把持形態のリストを表示する (図 4 左下).

3) ユーザは，対象物の置かれた状態や対象物の使用目的・用途から，物体を取り上げるのに適切な把持形態を

選択する。これにより，選択された把持形態で物体を取り上げるための作業モデルがシステムに渡される.

以上の操作により, クリック点に対応した対象物上の一点の三次元座標, 対象物が含まれるタスク空間モデル, 対象物のプリミティブ形状，指定された把持形態で物体を取り上げるための作業モデルがシステムに渡される. 


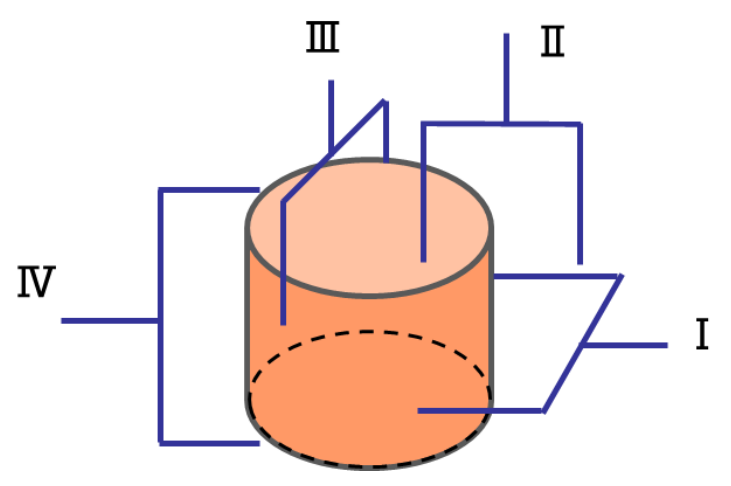

Fig. 5 Cylinder primitive

\section{3. 対象物情報の獲得と環境モデル構築}

作業指示で得られた情報を用いて，ステレオビジョンにより対象物情報の獲得と対象物周辺の環境モデルの構 築を行う.

\section{$3 \cdot 1$ 対象物情報の獲得}

把持に必要となる対象物情報は，物体プリミティブの形状と位置姿勢である．形状を表すパラメータの精度は， 物体の取り方と作業仕様に依存する，例えば，物体プリミティブが中空・底有り型円柱の場合，図 5 のように，四 つの代表的な把持形態が定義できる．把持形態 I, II, III の場合，ハンドの開閉ストローク内で物体把持が行えるか どうかを判定したり，指が円柱内部に挿入できるかどうかを判定するためには，円柱の半径に関する情報が必要 となる. そのため円柱の半径については精度が要求される。しかし，高さの情報については，対象物のサイズに 関する把持可能性の判定に用いられないので, それほどの精度は要求されない。一方，把持形態 IV の場合，八ン ドの開閉ストローク内で物体把持が行えるかどうかを判定するためには，高さの情報が必要となるため，高さに ついては精度が要求されるが, 半径の精度は要求されない.

対象物情報の獲得は，まずステレオカメラにより取得した距離画像を，ジャンプエッジを利用してセグメンテー ションし, その中からクリック操作で得られた対象物上の点が含まれる領域を抽出する. 次に, 抽出された領域 内の三次元点群情報を用いて，プリミティブ形状をフィッティングすることで作業に必要な対象物情報を得る. 高 い精度が要求される形状パラメータの取得においては, 必要に応じてマニピュレータの運動により視点を変更し てデータを収集する。一方, 精度が要求されない形状パラメータについては，物体モデルに記述された代表值を 用いたり，他の形状パラメータの取得過程で得られた三次元点群情報を用いて取得する.

具体例として，カップの器を中空・底有り型円柱プリミティブで表し，図 5 の把持形態 II, III を想定した対象物 情報獲得について示す．把持形態 II, III でカップを把持するためには，円柱開口部の縁円に関する情報が必要とな る.また，円柱の高さの情報も必要であるが，高い精度は要求されない，縁円情報の取得は，まずステレオカメ ラにより取得した距離画像から，対象物上の点が含まれる領域を抽出する（図 $6(\mathrm{a})$ )。次に, 抽出された領域の ガウス曲率と平均曲率から，その領域が円柱のどの部位（円柱外側面，円柱内側面，円柱外側底面，円柱内側底 面）に属するのかを判定し, 点群の法線情報を利用して円柱の中心軸を算出する（図 6 (b)）. 次に, 円柱の中心 軸とカメラ光軸のなす角度から, 縁円情報を取得するのに適切な視点から゙うかを判定し, 場合によっては, マニ ピュレータの運動により縁円を哯き込む位置にステレオカメラを移動して画像を取得する．縁円が表示された画

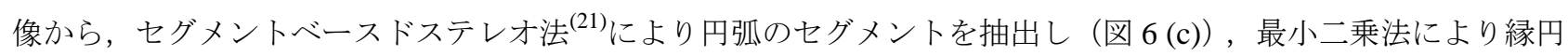
の半径と位置姿勢を求める（図 $6(\mathrm{~d})$ ) 。 円柱の高さは，図 $6(\mathrm{a})$ で抽出した領域の点群を円柱中心軸に投影し，投 影された点と縁円中心点との最大距離の值に設定する. 


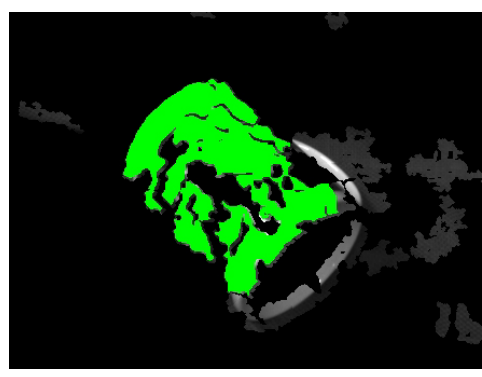

(a)

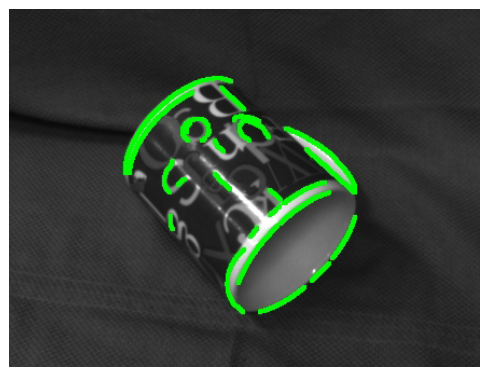

(c)

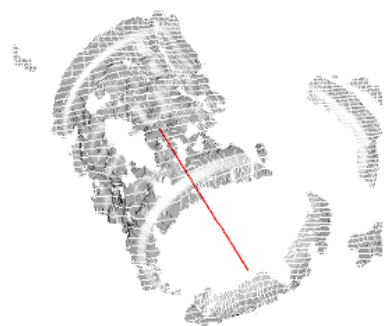

(b)

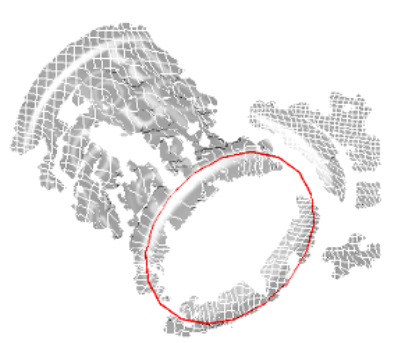

(d)

Fig. 6 Extraction of the circle of the brim

\section{$3 \cdot 2$ 環境モデル構築}

環境情報として，作業指示によりタスク空間モデルが得られている。しかし，その内部の対象物周辺の情報は 得られていない，対象物周辺の物体は，物体把持において障害物となるため，タスク空間モデルの空間領域内部 の情報が必要となる．そこで，ステレオビジョンにより対象物周辺の三次元情報を取得し，3D occupancy gridに より対象物周辺の環境モデルを構築する ${ }^{(19)}$. 3D occupancy grid は, 三次元空間を均等なサイズの voxel に分割し, 各 voxelには, 対象物が存在する領域（対象物領域）, 対象物以外の物体が存在寸る領域（物体領域）, 物体が存 在しない領域（空領域），物体の存在が未知である領域（未知領域），を表す四つの值が入る. 対象物周辺の環境 モデル構築手順は以下の通りである（図 7).

1) タスク空間モデルの空間領域を voxel に分割し，全ての voxel を未知領域の値とする（図 7 (a)）.

2) ステレオカメラで三次元情報を得る.

3）三次元点が含まれる voxel を物体領域の值にし，その voxel とカメラを結ぶライン上の voxel を空領域の值に する（図 7 (b), (c)) .

4) 未知領域の voxel が, 空領域に完全に被われている場合には, その voxel を空領域の值にする.

5) 視点を変えて 2)〜4) を適当な回数繰り返す.

6）対象物が含まれる voxel を対象物領域の值にする（図 7 (d)）.

環境モデルの構築は，対象物情報の獲得と同時に行われる.

\section{4. 把 持 計 画}

作業指示で得られた情報と，ステレオビジョンにより獲得した対象物情報・環境モデルを用いて把持計画を行 い, 最適な把持点を選定する. 把持点とは, 把持実行時におけるハンド座標系の参照位置・姿勢である. 把持点 は，作業モデルに記述されている全ての動作が実行できるように選定しなければならない。物体を取り上げる作 業は，アプローチ，把持，離脱の三つの動作により構成される．以下，それぞれの動作について説明する.

\section{アプローチ}

アプローチとは, ハンドを開いた状態で, 開放空間にある対象物近傍点（アプローチ開始点）から把持点まで移 動する動作である，アプローチは，以下の条件を満たさなければならない．

・アプローチ軌道は, マニピュレータの可動範囲内にある.

・アプローチ軌道上で, ロボットは環境と干渉しない. 


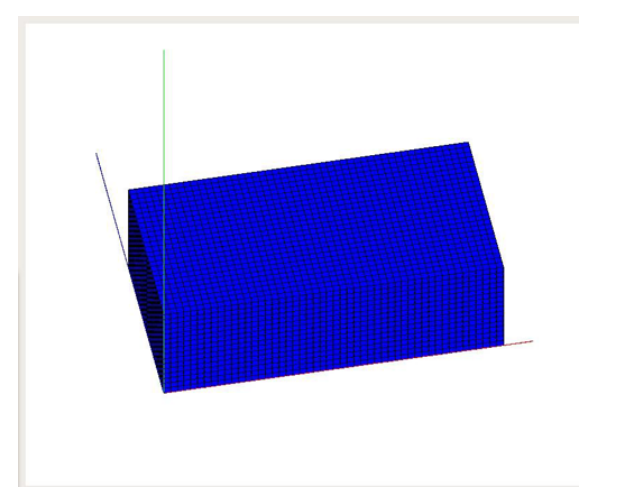

(a)

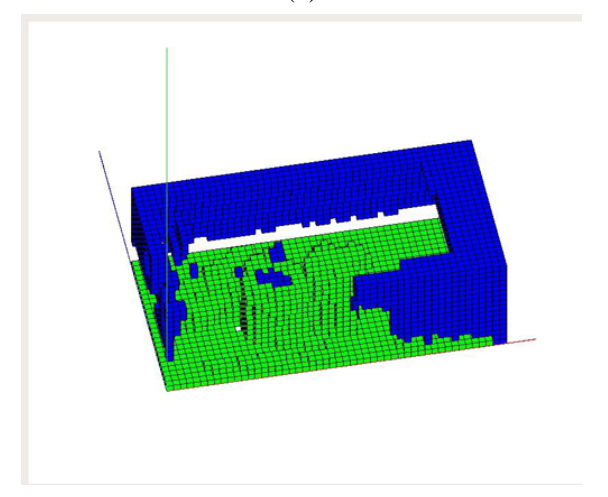

(c)

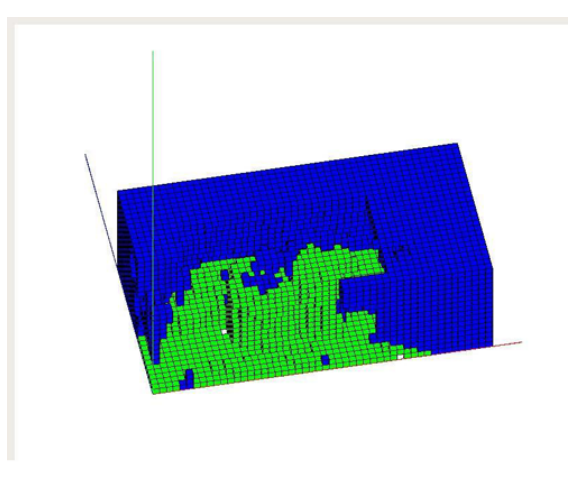

(b)

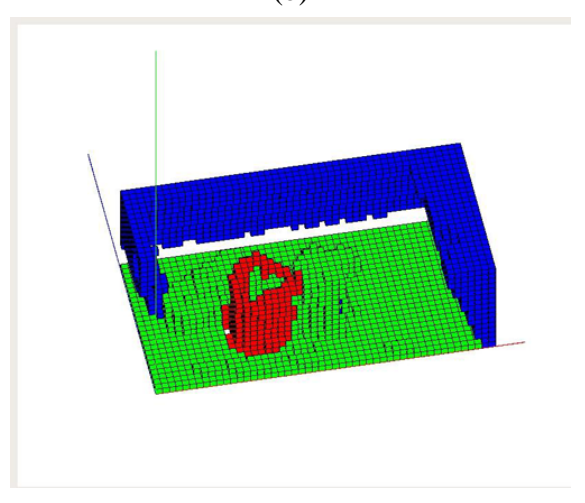

(d)

Fig. 7 3D occupancy grid model of the environment

\section{把持}

把持とは, 把持点において指を閉じることにより物体を捕獲する動作である. 把持は, 以下の条件を満たさなけ ればならない。

・把持点は, マニピュレータの可動範囲内にある.

・把持点において, ハンドは環境と干渉しない.

・指を閉じる前，ハンドは対象物と干渉しない.

・指を閉じたとき, 両指の内側面と対象物が接触する.

・指を閉じたとき, Force-Closure が成立する.

\section{離脱}

離脱とは，物体を把持して把持点から開放空間に移動する動作である。離脱は，以下の条件を満たさなければな らない。

・離脱軌道は, マニピュレータの可動範囲内にある.

・離脱軌道上で, ロボットおよび把持物体は環境と干渉しない.

\section{$4 \cdot 1$ 把持評価}

作業モデルに記述された三つの動作の実行条件は，1) ハンドと対象物との幾何学的条件，2) 力学的外乱に対す るロバスト性，3) マニピュレータのキネマティクス，4）障害物回避，に関するものである．そこで，これらの条 件を満たす把持点を選定するために，以下の把持評価を導入する.

\section{(a) ハンドと対象物との幾何学的条件}

ハンドと対象物との幾何学的条件には，サイズに関するものと位置に関するものがある，サイズに関する条件 には，指の開閉ストローク内で把持できる対象物のサイズなどの条件が含まれ，位置に関する条件には，把持前 にハンドと対象物が干渉しない把持点の範囲とか，指を閉じたときに指の間に対象物が存在する把持点の範囲な どの条件が含まれる．幾何学的条件は，それぞれ 


$$
\begin{gathered}
\boldsymbol{C}_{s}\left(\boldsymbol{O}_{g}, \boldsymbol{H}, G_{f}\right) \geq \mathbf{0} \\
\boldsymbol{C}_{p}\left(\boldsymbol{O}_{g}, \boldsymbol{H}, G_{f}, \boldsymbol{P}\right) \geq \mathbf{0}
\end{gathered}
$$

と表せる.ここで $\boldsymbol{C}_{s}$ は，サイズに関する幾何学的条件を列挙し，それをまとめてベクトル表記したもの， $\boldsymbol{C}_{p}$ は， 位置に関する幾何学的条件を列挙し，それをまとめてベクトル表記したものである．また， $\boldsymbol{O}_{g}$ は対象物の形状パ ラメータ, $\boldsymbol{H}$ はハンドの形状・機構パラメータ, $G_{f}$ は把持形態, $\boldsymbol{P}$ は把持点である.ここで, 式 (2) および式 (3) を満たす $\boldsymbol{P}$ が存在しないとき, ロボットは指定された把持形態で対象物を把持することができない. このときシ ステムは，指定された把持形態が実現できないことをユーザに通知する必要がある．把持点 $\boldsymbol{P}$ がとりうる範囲は 式(3) から求められ，その範囲を離散化して把持点候補のリストが作成される. ここで，ハンドと対象物との幾何 学的条件を評価するために, 以下の評価を導入する.

$$
\begin{gathered}
e_{h}=\min \left|c_{p i}\left(\boldsymbol{O}_{g}, \boldsymbol{H}, G_{f}, \boldsymbol{P}\right)\right|(i=1 \sim n) \\
E_{h}=e_{h} / e_{h \_ \text {max }}
\end{gathered}
$$

ここで, $c_{p i}\left(\boldsymbol{O}_{g}, \boldsymbol{H}, G_{f}, \boldsymbol{P}\right)$ は $\boldsymbol{C}_{p}$ の $i$ 番目の要素を表し, $n$ は要素数を表す。 また, $e_{h\lrcorner m a x}$ は，全ての把持点候補に おける $e_{h}$ の最大值である. 把持点 $\boldsymbol{P}$ が式 (3) を満たすとき, 式 (5) の評価值が高いほど式 (3) の境界から離れるこ とになり，把持位置の誤差に対するロバスト性が確保される.

\section{(b) Force Closure}

ロバストな把持の指標として Force Closure が良く用いられている(2)(4). Force Closure による評価は，まず指と 対象物との接触を複数の摩擦有り点接触の組合せで記述し，摩擦円錐を多面錘で近似した上で握力の上限を定め, wrench 集合を計算する. 摩擦係数に関しては安全率を見込んで小さめの值に設定し，多くの日用品に対して同一 の摩擦係数を用いて評価が行えるようにする. 次に, wrench 集合が貼る凸多面体の面と原点との距離を求め, そ の距離の最小值を Force Closure の評価值とする ${ }^{(20)}$. 本研究では，全ての把持点候補について Force Closure の評 価值を求め, その最大值で除することで評価值が $0 \sim 1$ となるように正規化したもの（ $E_{f}$ と表記）を評価に用い る. 尚, Force Closure の条件が満たされない場合は，評価值をゼロとする.

\section{(c) マニピュレータのキネマティクス}

マニピュレータで物体を把持するためには，把持点はマニピュレータの可動範囲内になければならない。 そこ でまず，把持点がマニピュレータの可動範囲内にあるかどうかをチェックする．把持点がマニピュレータの可動範 囲内になければ，その把持点を把持点候補のリストから除く. 次に，マニピュレータが把持点に到達しやすいかど うかを評価する。マニピュレータのキネマティクスを評価するため, 次の評価式を導入する.

$$
\begin{gathered}
e_{p}=1-\left(\Delta p-\Delta p_{\min }\right) /\left(\Delta p_{\max }-\Delta p_{\min }\right) \\
e_{r}=1-\Delta \theta / \pi \\
E_{k}=\alpha_{1} e_{p}+\alpha_{2} e_{r} \\
\alpha_{1}+\alpha_{2}=1
\end{gathered}
$$

ここで, $\Delta p$ はマニピュレータの基準位置と把持位置の距離， $\Delta \theta$ は基準姿勢と把持姿勢との間の姿勢変化量を表 す. $\Delta p_{\max }, \Delta p_{\min }$ は, $\Delta p$ の最大值と最小值である.また， $\alpha_{1}, \alpha_{2}$ は評価值の重み係数である. $\Delta p$ または $\Delta \theta$ が 0 となるときは $\alpha_{1}$ または $\alpha_{2}$ を 0 とする。この評価值が高ければ，マニピュレータは少ない移動量で把持点に到 達できる. 


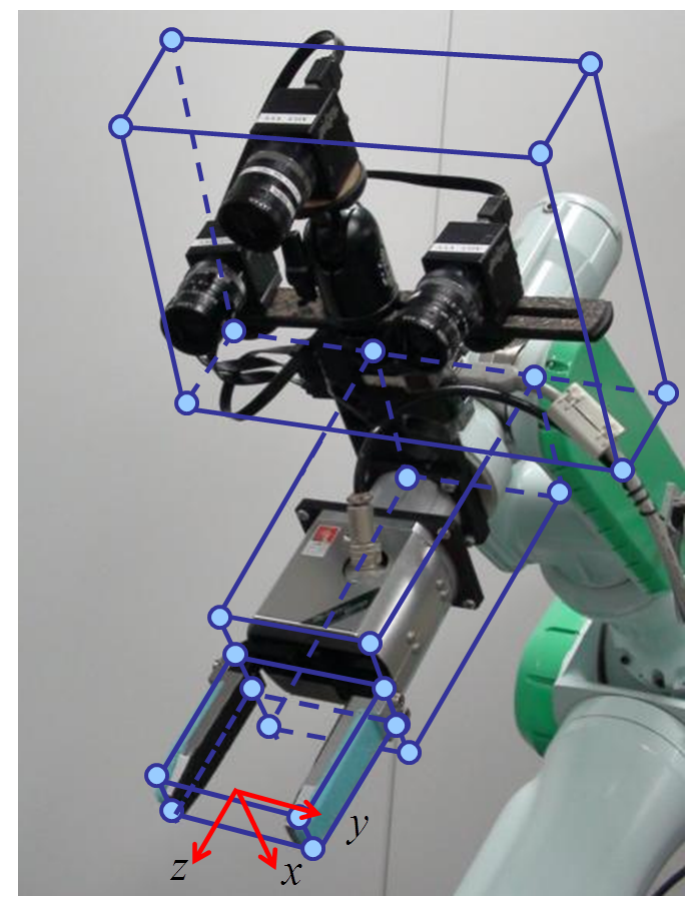

Fig. 8 Model of the end-efector with three boxes

\section{(d) 障害物回避}

3D Occupancy grid で表された環境モデルの物体領域と未知領域の voxel は, 障害物となりうる領域（障害物領 域）である。ロボットは把持点において，これら障害物領域の voxel との干渉を回避しなければならない，そこで 図 8 に示すように, マニピュレータの先端部を, エンドエフェクタおよびステレオカメラを内包する直方体で近似 し, この直方体と障害物領域の voxel との最小距離を評価する. 把持点において, 障害物領域の voxel がマニピュ レータ先端の直方体内部にあるとき，障害物とエンドエフェクタは干渉する可能性があるので，その把持点を把 持点候補のリストから削除する。ここで，エンドエフェクタと物体との距離がある程度以上離れている場合には， その物体は把持作業において障害とはならない，そこで，評価で用いる距離に上限を設け，物体がこの上限より 遠方にある場合には，障害物が存在しないものとして扱う。ここで，障害物回避のため，以下の評価を導入する.

$$
E_{e}= \begin{cases}1.0 & \left(l(\boldsymbol{P})>l_{\text {sup }}\right) \\ l(\boldsymbol{P}) / l_{\text {sup }} & \left(l(\boldsymbol{P}) \leq l_{\text {sup }}\right)\end{cases}
$$

ここで, $l(\boldsymbol{P})$ はマニピュレータ先端部の直方体と障害物領域の voxel との最小距離， $l_{\text {sup }}$ は評価で用いる距離の上 限である.

\section{$4 \cdot 2$ 把持点選定}

把持点の選定は, 以下の手順で行う.

1) TSM の許容アプローチ方向の条件を満たす把持点（把持姿勢が関係する）において，式 (3) から把持点がと りうる範囲を求め, その範囲を離散化して把持点候補のリストを作成する.

2) 各把持点候補に対して, 以下の式に基づく把持評価を行う.

$$
E=w_{1} E_{h}^{2}+w_{2} E_{f}^{2}+w_{3} E_{k}^{2}+w_{4} E_{e}^{2}
$$

ここで $w_{1} \sim w_{4}$ は重み係数である. 


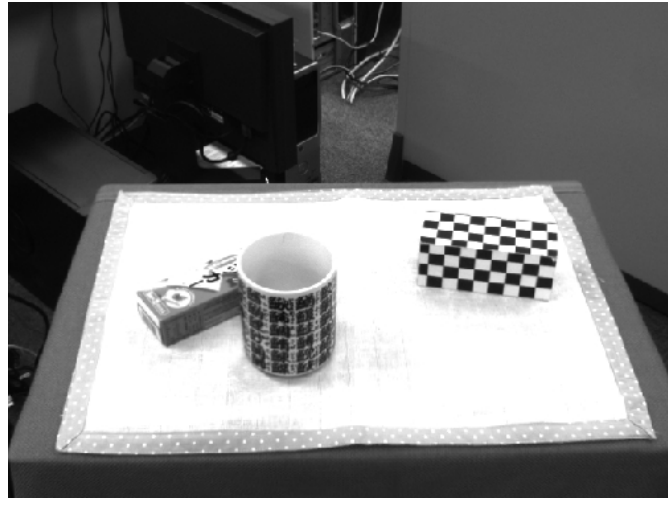

(a)

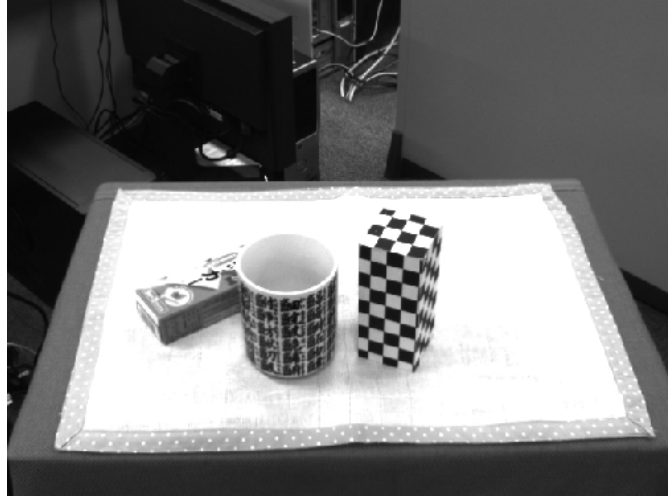

(b)

Fig. 9 Arrangement of the objects

尚，把持点候補がマニピュレータの可動範囲外であったり，障害物と干渉する場合には，その把持点候補を 把持点候補のリストから削除する.

3) 式(11)の評価值が最高となる把持点候補を選出する.

4) 選出された把持点候補に対して，アプローチ動作と離脱動作が実行可能かチェックする.アプローチ動作と離 脱動作のチェックは, 両動作の軌道を離散化した点に対して, マニピュレータの可動範囲チェックと, 障害物 との干渉チェックを行う。

5) アプローチ動作，離脱動作が可能ならば，その把持点候補を把持点とする.

6) アプローチ動作または離脱動作が実行できない場合は，次に評価值の高い把持点候補を選出し，4＜wide>６）を把 持点が見つかるまで行う。

\section{5. 実 験}

本手法の有効性を確認するために，人が指示した物をロボットで取り上げる実験を行った。実験は，三菱重工 （株）製のロボットアーム Pa10に，高野ベアリング（株）（現シュンク・ジャパン（株））製のミューグリッパと， 3 眼のステレオカメラを取り付けて行った. ハンド座標系は，指先端部より $20 \mathrm{~mm}$ 内側の指間の中心位置に，図 8 に示すように設定した. ステレオカメラの基線長は 130mm であり, 使用したカメラは POINT GREY RESEARCH 社の IEEE1394a カメラ Flea VGA, B/W, 8bit で，焦点距離 $6 \mathrm{~mm}$ 相当のレンズを用いている.

実験では，ユーザの指示に従ってテーブルの上にあるコップを取り上げる作業と，棚の中にあるコップを取り 上げる作業を行った。

\section{実験 $1:$ テーブル上の物体把持}

まず，テーブルの上に図 9 (a), (b) の状態で置かれたコップをユーザの指示に従って取り上げる実験を行った. 図 9 (a) では，対象物の近くに障害物は存在しないが，図 9 (b) には障害物が存在する。システムには，予めテーブ ルのタスク空間モデルが実際の配置に合わせて記述されており，テーブルのタスク空間モデルには，缶ジュース， コップ，マグカップの三種類の物体モデルが登録されている。しかし，システムには，ユーザがどの物体を把持対 象とするのか, また, 対象物のサイズや位置姿勢, 対象物の周辺にある物体などの情報は一切与えられていない.

図 10 は，ユーザが作業指示を行っているときのディスプレイ画面である. ディスプレイには, マニピュレータ の手首に取り付けたステレオカメラの中の一つの画像が表示されている（図 10(a)）。ユーザは, このカメラ画像 上で対象物（コップ）を指定してクリックした。すると，ステレオビジョンによりクリック点に対応した対象物上 の点の三次元座標が得られ，その点が含まれているテーブルのタスク空間モデルが選定される. システムは，こ のテーブルのタスク空間モデルに登録されている物体モデルのアイコンリストを表示する（図 10(b)）。ユーザは, この物体モデルのアイコンリストの中から対象物の種類を指定してクリックする. 実験ではコップを指定してク リックした。すると，システムはコップの物体モデルに登録されている把持形態のリストを表示する（図 $10(\mathrm{c}))$. ユーザは，表示された把持形態のリストの中から，対象物の置かれた状態や使用目的・用途に応じて適切な把持形 


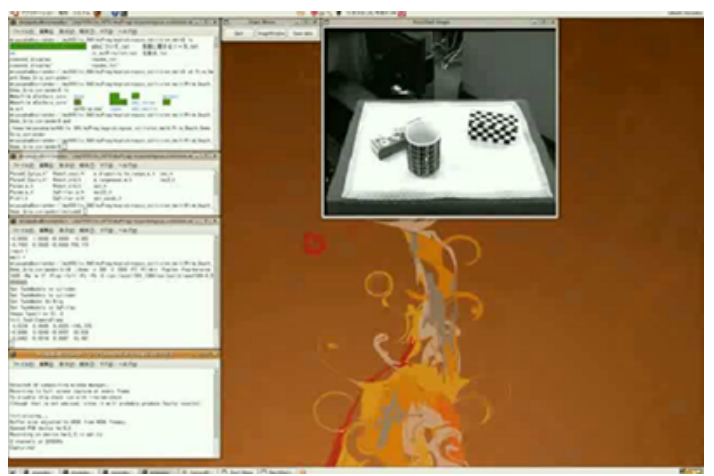

(a)

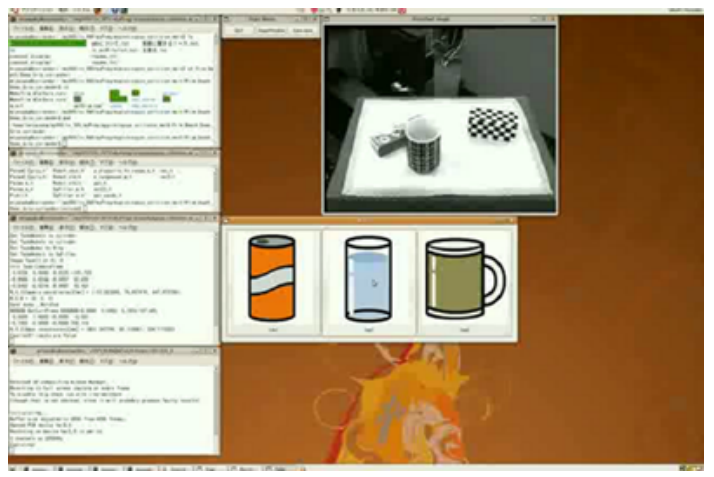

(b)

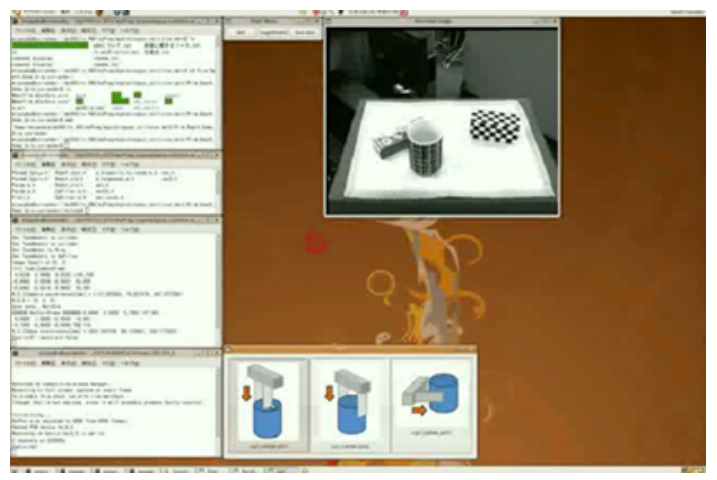

(c)

Fig. 10 Screenshot of the task instruction

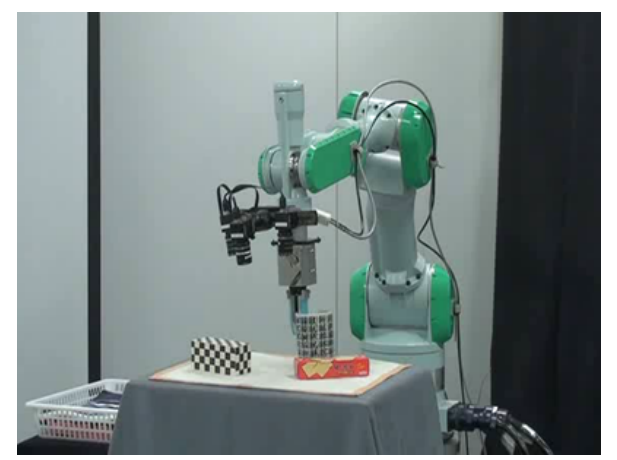

(a)

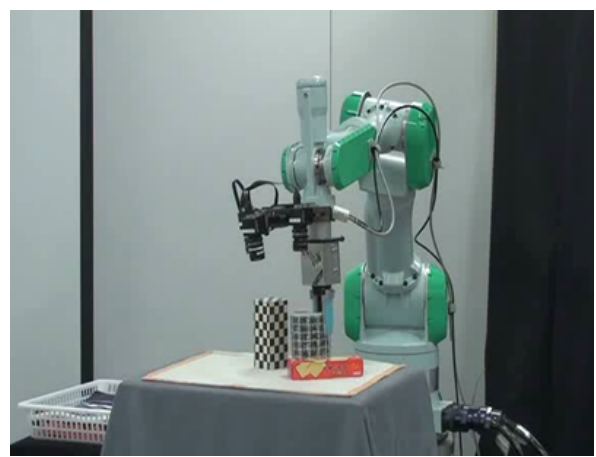

(b)

Fig. 11 Experimental scene of the grasping a cup on the table

態を選択する．実験では，コップの後片付けを想定し，コップの縁を把持する把持形態（図 5 把持形態 II）を選 択した。コップの縁を把持して取り上げる作業の実装では，アプローチ動作の軌道は直線で，アプローチ方向は 


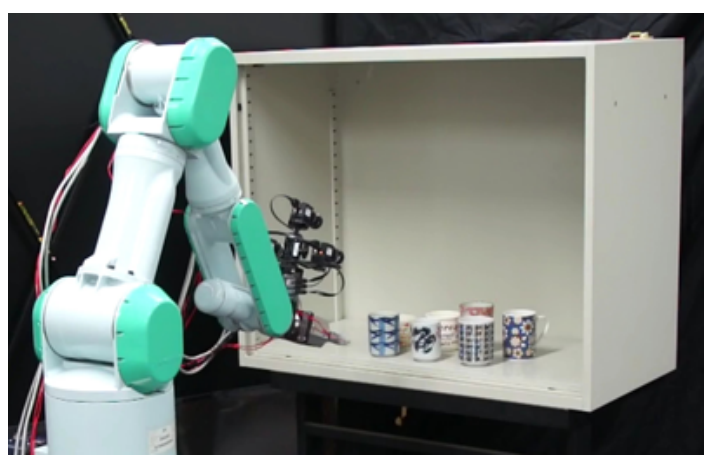

Fig. 12 Setup of the second experiment

円柱中心軸に沿って開口部から底に向から方向とした．また，離脱動作の軌道は直線で，離脱方向は鉛直上方向 としている. 次に, 作業指示で得られた情報を用いて, 高機能三次元視覚システム VVV ${ }^{(22)}$ のステレオビジョンに より，対象物情報の獲得と対象物周辺の環境モデル構築を行い，獲得した対象物情報と環境モデルを用いて把持 計画を行い把持点を選定した。把持計画において，コップの縁を把持する把持形態の場合，式 (2)には，指の開閉 ストローク内で把持できるコップのサイズに関する条件に加えて，片方の指がコップの内側に挿入できるサイズ の条件が記述されている。また，式 (3)には，ハンドとコップが干涉しない把持深さに関する条件が記述されてい る. テーブルの TSM に記述されている許容アプローチ方向の条件と式(2)(3)により，ユーザが指定した把持形態 で物体把持が可能かチェックを行い，把持が不可と判定された場合には，エラーメッセージを表示して作業指示の 最初に戻る. 次に, 式(3) から把持点候補のリストを作成し, 把持評価により把持点を選定した. 図 11(a), (b) は, 図 9(a), (b) の状態で置かれた対象物の把持点を把持計画により選定し，物体把持を行っている実験シーンである. 図 11 (a) では, マニピュレータのキネマティクスの評価を反映して, マニピュレータの移動量が少ない把持点が 選定された。 また, 図 11 (b) では, 障害物回避の評価を反映し, 障害物のある側と反対側の把持点が選定された. 尚, 今回の実験では, 式 (8)の重み係数は $\alpha_{1}=\alpha_{2}=0.5$ とし, 式(11)の重み係数は $w_{1}=w_{2}=w_{3}=w_{4}=0.25$ と して把持点を求めた.

\section{実験 $2:$ 棚の中の物体把持}

次に，図 12 に示す棚の中にあるコップをユーザの指示に従って取り上げる実験を行った．棚のタスク空間モデ ルに登録してある物体モデル，および作業指示の手順については実験 1 と同様である. 実験では, ユーザはシステ ムが表示した把持形態のリストの中から，コップの側面を把持する把持形態（図 5 把持形態 I）を選択した. コッ プの側面を把持して取り上げる作業の実装では，アプローチ動作の軌道は直線で，アプローチ方向は把持点におけ るハンド姿勢の $\mathrm{z}$ 軸方向（図 8）とした. また, 離脱動作の軌道は直線で, 離脱方向は鉛直上方向としている. 次 に，システムはステレオビジョンにより対象物情報と対象物周辺の環境モデルの構築を行った。図 13 は, 対象物 モデル獲得の様子を示したものである. 図 13(a) はステレオビジョンにより得られた点群データであり，図 13(b) はクリック操作で得られた対象物領域（緑色）とセグメントベースドステレオ法により得られたコップ飲みロの 円弧を表示したもの，図13(c) は獲得された対象物モデルである. 次に，獲得した対象物情報と対象物周辺の環境 モデルを利用して把持計画を行い把持点を求めた。今回の実験では，把持位置は獲得した円柱プリミティブの中 心とし，把持点におけるハンド姿勢の $\mathrm{y}$ 軸が円柱中心軸と直交する条件のもとで把持姿勢を求めた。把持計画に おいて，コップの側面を把持する把持形態の場合，式(2)には，指の開閉ストローク内で把持できるコップのサイ ズに関する条件に加えて, 把持位置を円柱中心に設定することができる条件（指長さ－円柱半径 $>0$ ）が記述さ れている. また, 式 (3) には, ハンドとコップが干渉しない把持姿勢に関する条件が記述されている. 棚の TSM に記述されている許容アプローチ方向の条件（棚の上面，側面，背面，底面からのアプローチは禁止されている） と式 (2)(3)により，ユーザが指定した把持形態で物体把持が可能かチェックを行い，把持が不可と判定された場合 には，エラーメッセージを表示して作業指示の最初に戻る。今回の実験では，ユーザがコップの側面把持以外を選 択した場合には，エラーメッセージを表示して作業指示の最初に戻ることになる. 図 14 は把持計画により把持姿 勢を選定している様子である. 図 14(a) は把持姿勢（把持点におけるハンド座標系 $\mathrm{z}$ 軸を表示）の全候補であり， 図 14(b) は式(2)(3) によるチェック後の把持姿勢候補, 図 14(c) は把持計画により選定された把持姿勢である.今 


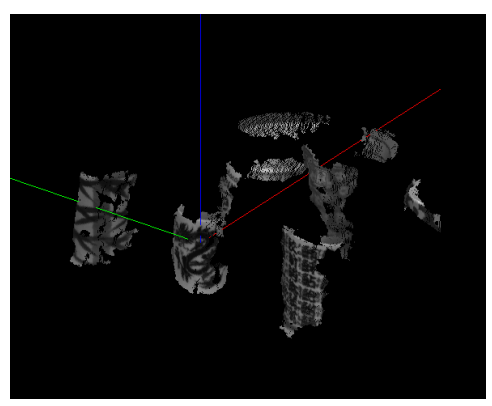

(a)

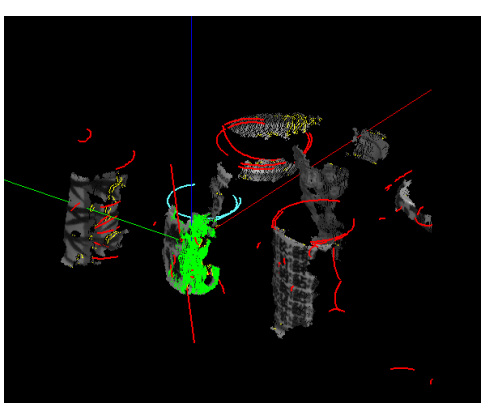

(b)

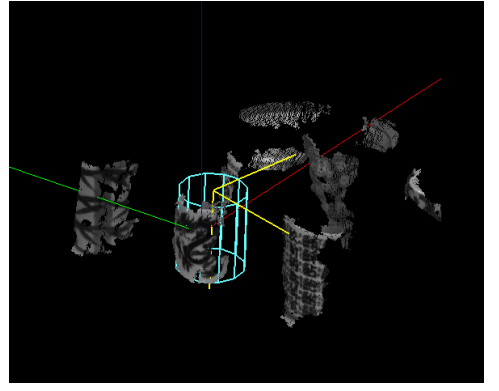

(c)

Fig. 13 Acquisition of the object model

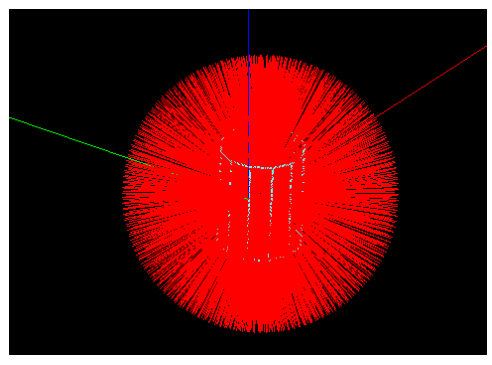

(a)

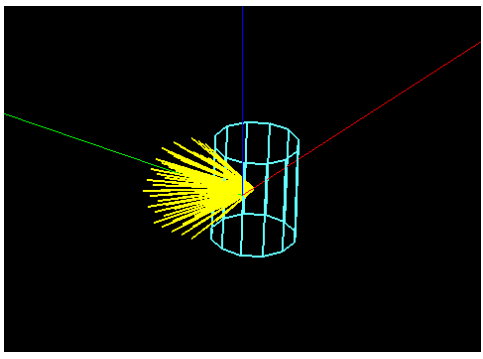

(b)

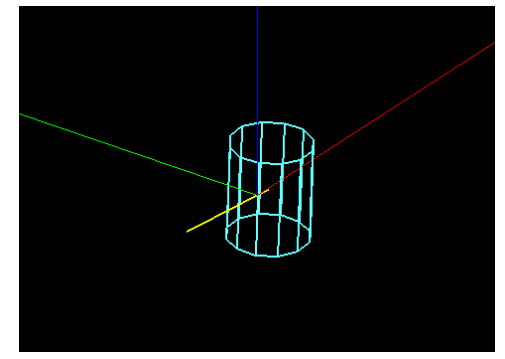

(c)

Fig. 14 Grasp planning for the side grasp

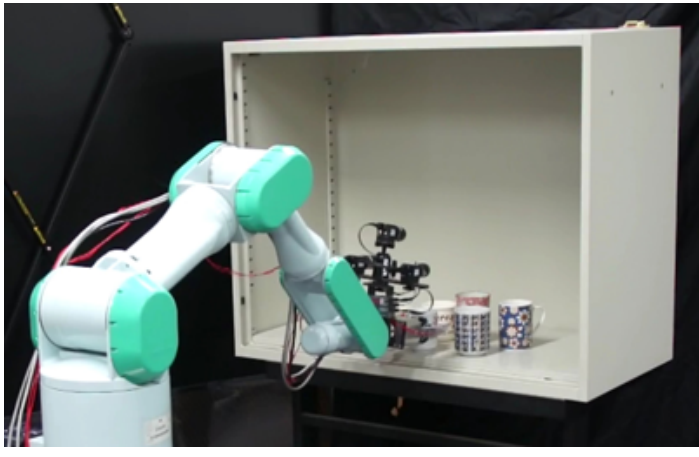

(a)

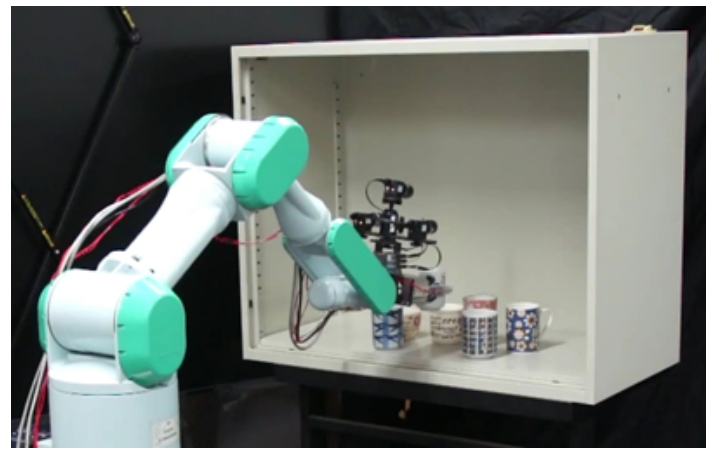

(b)

Fig. 15 Experimental scene of the grasping a cup in the shelf

回の把持計画では，把持位置は一定であり ForceClosure の評価值もほぼ一定となることから，その重み係数を 0 とし, 式(8)の重み係数は $\alpha_{1}=0.0, \alpha_{2}=1.0$, 式(11)の重夕係数は $w_{1}=0.1, w_{2}=0.0, w_{3}=0.2, w_{4}=0.7$ として 把持姿勢を求めた。把持計画における重夕係数の設定は，物体が置かれた様々な状況に対して実験を重ね，バラ ンスの良い重み係数を見つける必要がある.

図 15 は実験の様子を示したものである.今回での実験では，物をどけて対象物を把持するといったマニピュレー ションを伴う物体把持については未対応であるため, 奥にある物体の把持は行っていないが，棚の中の手前にあ るコップについては，大きさやテクスチャが異なってもユーザの指示により取り上げることに成功した.

\section{6. 結 言}

本論文は，対象物の周辺に隣接物体が存在するような複雑な環境下で，人が指示した物を取り上げる作業指示 システムを提案した。本作業指示システムにおける指示物体の把持は，次の四つのステップにより実行される.

1) ユーザはクリック操作とメニュー選択により, 対象物と, その取り方を指定し, ロボットに作業指示を行う.

2）作業指示で得られた情報を用い，ステレオビジョンにより対象物情報の獲得と, 対象物周辺の環境モデルを 
構築する.

3）獲得した対象物情報と環境モデルを用いて把持計画を行い，最適な把持点を選定する.

4) ロボットは選定された把持点で対象物を把持して取り上げる.

本作業指示システムの特徵は，物体モデルは個々の物体についてではなく，物体のカテゴリ毎に定義しているこ と，また，家具や建具のタスク空間モデルに登録する物体モデルも，個々の物体についてではなく，普段ユーザが 置いている物体カテゴリを登録していることである.これにより，多種多様な日用品を少ない数の物体モデルで 記述でき，生活支援ロボットの適用範囲を広げることができる。また，物体モデルと，その物体モデルに適用可 能な作業モデルをデータベースとして蓄えておき, ユーザが数回のクリック操作とメニュー選択によりロボット に作業指示を与えることで，予めシステムに個々の物体に関する情報を与えなくても，対象物および対象物周辺 の情報をその場で獲得して対象物を取り上げることができる.

最後に本手法を検証するために，二つの異なった環境に置かれた物体に対してユーザの作業指示により物体を 取り上げる実験を行い, 本手法の有効性を確認した。

本作業指示システムでは，家具や建具などのタスク空間モデルに物体モデルを登録する必要がある. タスク空 間モデルへの物体モデルの登録・解除はユーザが行う必要があり, クリック\&ドラッグなどの簡単な操作で物体モ デルの登録・解除が行えるようなユーザインタフェースの開発が必要であると考えている．また，現在のシステ ムでは，ユーザによる作業指示でクリックミスが生じた場合や，物体モデルが登録されていない物をユーザが指 定した場合には, 手動操作モードに切り替えて遠隔操作により対象物を把持している. 今後の課題として，作業 指示でミスが発生した場合のエラーリカバリーや，物体モデルが登録されていない物を指定した場合の対処につ いて検討して行く予定である. 更に, より複雑な環境下での物体把持を可能にするため, 家具の扉や引き出しを 開けて物を取り出したり，奥にある物を取るために手前の物をどけたり，対象物を滑らせて取るといったマニピュ レーションを伴う把持についても検討していく予定である.

\section{文献}

(1) 平井成興, “Shared Autonomy の理論”, 日本ロボット学会誌, Vol. 11, No. 6 (1993), pp. 788-793.

(2) Miller, A.T., Knoop, S., Christensen, H.I., and Allen, P.K., "Automatic Grasp Planning Using Shape Primitives”, Proceedings of IEEE International Conference on Robotics and Automation (2003), pp. 1824-1829.

(3) Ekvall, S., and Kragic, D., "Learning and Evaluation of the Approach Vector for Automatic Grasp Generation and Planning", Proceedings of IEEE International Conference on Robotics and Automation (2007), pp. 4715-4720.

(4) Berenson, D., Diankov, R., Nishiwaki, K., Kagami, S., and Kuffner, J., “Grasp Planning in Complex Scenes”, Proceedings of IEEE International Conference on Humanoid Robots (2008), pp. 42-48.

(5) Huebner, K., and Kragic, D., "Selection of Robot Pre-Grasping using Box-Basecd Shape Approximation", Proceedings of IEEE/RSJ International Conference on Intelligent Robots and Systems (2008), pp. 1765-1770.

(6) Yamazaki, K., Tomono, M., Tsubouchi, T., and Yuta, S., "A Grasp Planning for Picking up an Unknown Object for a Mobile Manipulator", Proceedings of IEEE International Conference on Robotics and Automation (2006), pp. 2143-2149.

(7) 香月理絵, 太田順, 田村雄介, 水田貴久, 鬼頭朋見, 新井民夫, 植山剛, 西山強志, “マークを用いたロボットの多種類物体ハン ドリング”, 日本機械学会論文集 C 編, Vol. 70, No. 691 (2004), pp. 766-773.

(8) Chong, N.Y., Hongu, H., Ohba, K., Hirai, S., and Tanie, K., “A Distributed Knowledge Network for Real World Robot Applications", Proceedings of IEEE/RSJ International Conference on Intelligent Robots and Systems (2004), pp. 187-192.

(9) Makihara, Y., Takizawa, M., Ninokata, K., Shirai, Y., Miura, J., and Shimada, N., “A Service Robot Acting by occasional Dialog - Object Recognition Using Dialog with User and Sensor-Based Manipulation -", Journal of Robotics and Mechatronics, Vol. 14, No. 2 (2002), pp. 124-132.

(10) Saito, F., and Suehiro, T., "Toward Telemanipulation via 2-D Interface - Concept and First Result of "Titi" -", Proceedings of the 2002 28th Annual Conference of the IEEE Industrial Electronics Society, Vol. 3 (2002) pp. 2243-2248. 
(11) Neubert, J., Ravindran, P., and Ferrier, N.J., "An Assistive Robot Interface for an Interactive Visually Guided Grasping System”, Proceedings of the 8th International Conference on Rehabilitation Robotics (2003), pp. 290-293.

(12) Nguyen, H., Jain, A., Anderson, C., and Kemp, C.C., "A Clickable World: Behavior Selection Through Pointing and Context for Mobile Manipulation”, Proceedings of IEEE/RSJ International Conference on Intelligent Robots and Systems (2008), pp. 787-793.

(13) 永田和之, 脇田優仁, 小野栄一, “空間への作業情報貼付によるロボットへの作業教示”, 日本機械学会論文集 C 編, Vol. 74, No. 738 (2008), pp. 346-352.

(14) Nagata, K., and Yamanobe, N., "Picking up a Towel by Cooperation of Functional Finger Actions", Proceedings of IEEE/RSJ International Conference on Intelligent Robots and Systems (2010), pp. 1785-1790.

(15) Ikeuchi, K., and Suehiro, T., "Towards an assembly plan from observation: Part 1: Assembly task recognition using face-contact relations (polyhedral objects)", Proceedings of IEEE International Conference on Robotics and Automation (1992), pp. 21712177.

(16) Miura, J., Yano, Y., Iwase, K., and Shirai, Y., “Task Model-Based Interactive Teaching”, Proceedings of IROS 2004 Workshop on Issues and Approaches to Task Level Control (2004), pp. 4-11.

(17) Yamanobe, N., and Nagata, K., "Grasp Planning for Everyday Objects Based on Primitive Shape Representation for Parallel Jaw Grippers”, Proceedings of IEEE International Conference on Robotics and Biomimetics (2010), pp. 1565-1570.

(18) 川端聡, 永田和之, 河井良浩, “環境に固定されたマーカを用いたハンドアイキャリブレーション”, 画像の認識・理解シンポ ジウム (MIRU2009) 論文集 (2009), pp. 825-832.

(19) Elfes, A., "Sonar-Based Real-World Mapping and Navigation”, IEEE Journal of Robotics and Automation, Vol. 3 , No. 3 (1987), pp. 249-265.

(20) Ferrari, C., and Canny, J., "Planning Optimal Grasps", Proceedings of IEEE International Conference on Robotics and Automation (1992), pp. 2290-2295.

(21) Sumi, Y., Kawai, Y., Yoshimi, T., and Tomita, F., “3D Object Recognition in Cluttered Environments by Segment-Based Stereo Vision”, International Journal of Computer Vision, Vol. 46, No. 1 (2002), pp. 5-23.

（22）富田文明, “高機能 3 次元視覚システム VVV”, 情報処理, Vol. 42, No. 4 (2001), pp. 370-375. 